\title{
Farmers' perception on agricultural technologies a case of some improved crop varieties in Ghana
}

\author{
Emmanuel Asiedu - Darko \\ Council for Scientific and Industrial Research-Plant Genetic Resources Research Institute, Bunso Eastern Region, Ghana
}

Email address:

easiedudarko@yahoo.com

\section{To cite this article:}

Emmanuel Asiedu - Darko. Farmers' Perception on Agricultural Technologies a Case of Some Improved Crop Varieties in Ghana. Agriculture, Forestry and Fisheries. Vol. 3, No. 1, 2014, pp. 13-16. doi: 10.11648/j.aff.20140301.13

\begin{abstract}
The survey was carried out to find out farmers perception on improved crop varieties from March to June 2012 in the Ashanti, Eastern, and Northern regions of Ghana. Adoption of farming technologies is very crucial to agricultural development. In Ghana, a greater percentage $(70 \%)$ of the people is in the agricultural sector. Improvement in agriculture will have direct positive impact on the livelihood of the people. Farmer perception on agricultural technology influences their decision to adopt the technology or not. The study revealed that farmers perceived the improved crop varieties with particular reference to Maize (Zea maize), Cassava (Manihot esculentus) and Oil Palm (Elaies guineensis) as lacking some good characteristics of the landraces and also expensive to adopt. The need for farmers to be actively involved in the development of improved crop varieties was also highlighted. The study recommends that all stakeholders (Plant Breeders, Agronomists, Post Harvest Technologists, Ministry of Food and Agriculture (MOFA) and Farmers) should be actively involved in the development of farming technologies.
\end{abstract}

Keywords: Perception, Improved Crop Variety, Agricultural Technologies, Farmer

\section{Introduction}

Agricultural research activities have given birth to several improved crop varieties in Ghana. The agricultural institutions under the Council for Scientific and Industrial Research (CSIR) notably Crops Research Institute (CRI) and Savannah Agricultural Research Institute (SARI) have released several improved crop varieties to improve agricultural activities in the country. Some of these improved varieties include the following: Aziga, Golden Jubilee, Etubi (Maize varieties), Agbelifia, Esam bankye, bankye hemaa, Nyeri-kogba (Cassava varieties), EdorpoMunikpa, Kpaneli, (Groundnut varieties) and Zaayura and Songotra (Cowpea varieties). These improved crop varieties are introduced to farmers by Extension Department of Ministry of Food and Agriculture (MOFA).

The number of people working in the agricultural sector worldwide remains substantial. According to Food and Agriculture Organization (FAO, 2000) about $96.5 \%$ of these people live in developing countries. The active agricultural population had appreciated by nearly $60 \%$ in developing countries over the last 25 years, regardless of increasing urbanization (FAO, 2000)

The FAO report for the year 2000 revealed that in spite of this increase, availability and affordability of food is a major problem in many developing countries. Half of the world's population is still underfed and affected by some form of malnutrition and nutrient deficiency diseases which often have tragic health consequences.

Agriculture dominates Ghana's economy as the single largest contributor to Gross Domestic Product (GDP) while majority of the Ghanaian population, especially rural folks depend on it as the main source of livelihood. In 2008 agriculture's percentage contribution to GDP and Foreign Exchange was $33.6 \%$ and $37.9 \%$ respectively, (ISSER, 2008).

It is also a source of employment, employing more than half the population on a formal and informal basis, and accounting for almost half of GDP and export earnings, thus a major foreign exchange earner for the country (Osabutey, 2009).

In terms of agricultural performance Ghana has not done badly at all but the question is will Ghana be able to sustain the recent impressive agricultural performance? The need to keep pace with current agricultural activities and not to derail the current trend should be aligned with technological changes in the agricultural sector. Increased agricultural productivity depends primarily on accepting 
cultural and technological changes at the rural farm level. Peasant farmers could improve their productivity if they adopt improved farming techniques; however, some new practices are sometimes complicated, making adoption difficult for non-literate farmers (Apantaku, et al 2008). Peasant farmers must understand these farming techniques before they can adopt and successfully use them and this requires effective teaching by agricultural extension service (agents) ( Kesley and Hearne, 1995). According to Farinde and Jibowo (1996), the adoption and use of any extension teaching method depends on characteristics of the method, the type of audience to be reached by extension workers and the type of message (agricultural innovation) to be disseminated.

Farmers continuous use of landraces traditional (low yielding varieties) will make it difficult for the government vision to achieve agricultural growth rate of $4 \%$ as envisaged in the country's Vision 2020 a mirage.

One of the key factors that influence the farmers decision to adopt or not to adopt farming technology is the perception associated with the technology which are sometimes backed by cultural and traditional considerations.

Perception as defined by Van de Ban and Hawkin (1988) is the process by which information or stimuli is received and transformed into psychological awareness. Norton and Mumford posited that on the basis perception the farmer weighs the benefits to be derived from adopting the technology before a decision was reached

The objective of the study was to ascertain farmers perception on improved crop varieties and seeks answers on the following:

1. The reasons behind why farmers have certain perception on some improved crop varieties.

2. How these perceptions influence farmers decisions to adopt improve crop varieties.

\section{Materials and Methods}

The research adopted the descriptive and explanatory survey research design. This is because the study was aimed at describing how farmers perception affect adoption of farming technologies and explain its effects on agricultural productivity Data was collected from farmers within the operational areas of the Council for Scientific and Industrial Research namely Ejura, (Lat. $0.7^{0} 40^{\prime} \mathrm{N}$ ) Nyapkala(Lat. $0.9^{0} 28^{\prime} \mathrm{N}$ ) and Kusi (Lat.0.5 $54^{\circ} \mathrm{N}$ The target population for the study was farmers in these areas

Three hundred farmers made up of 225 males and 75 females were sampled randomly from the population of 446 farmers who grow maize, cassava, oil palm, cowpea and millet. A list of farmers groups in the operational areas which was obtained from extension agents at the operational areas was used for the sampling of the respondents. Questionnaire was used to solicit responses from the farmers. In addition, four different focus group discussions involving 15 farmers in each group were also conducted to collect qualitative data for the study. Farmers who are direct beneficiaries of technologies developed by CSIR scientists were targeted for focus group discussion.

\section{Results and Discussions}

The main crops cultivated by the respondents are cereal (maize, millet sorghum beans), root and tuber (cassava) and oil palm. These crops are cultivated on subsistence level with the surplus offered for sale to generate income.

Even though some of the farmers had adopted some improved crop varieties, majority of the farmers grow the improved and the traditional varieties. However substantial number of the farmers were still holding on to the traditional crop varieties thus these farmers had not adopted any kind of improved crop varieties (Table 1).

Table 1. Technology used by farmers

\begin{tabular}{lll}
\hline Technology used & Frequency & Percentage \\
\hline Improved crop varieties only & 123 & 41 \\
Traditional crops only & 84 & 28 \\
Both & 93 & 31 \\
Total & 300 & 100 \\
\hline
\end{tabular}

Farmers who grow both traditional and improved crop varieties argued that some traditional crops still have desirable traits such as good taste and ease of preservation which the improved crop varieties lack.

The respondents who have not adopted any technology (improved crop varieties) were of the view that it is expensive to adopt new technologies. The farmers thus explained that using the improved crop varieties required inputs such as fertilizers and other chemicals, which they could not afford. Some of the farmers interviewed maintained that at times farmers who cultivated the improved varieties had bumper harvest but found it difficult to market the produce. On the more serious note the respondents stated that they found the improved crop varieties lacking some desirable traits such as good taste and ease of preservation as indicated on Table 2.

Table 2. Reasons cited by farmers for non adoption of improved crop varieties

\begin{tabular}{lll}
\hline Reason & Frequency of responses & Percentage (\%) \\
\hline Taste & 46 & 24.47 \\
Ease of Preservation & 62 & 32.98 \\
Ready Market & 42 & 22.34 \\
Cost of Production & 38 & 20.21 \\
Total & 188 & 100 \\
\hline
\end{tabular}

Majority of respondents (72\%) indicated that that they had adopted improved crop varieties whilst $28 \%$ said they had not adopted any improved crop varieties. The reasons cited by these farmers for non-adoption included; ease of preservation, taste, ready market and cost of production.

They also complained about their marginalization in the planning and execution of the dissemination activities. 
The knowledge and experience of the farmers play a vital role in the dissemination and adoption of new technologies. Cohen and Levinthal (2000) stated in the theory of absorptive capacity that, there should the willingness by the scientists to incorporate farmer's local innovations into their research activities and also the local farmers should be willing to share their local knowledge. This would help make dissemination of technologies very easy which would increase adoption rate.

To bring a greater cooperation between farmers and researchers there was the need to incorporate farmers knowledge in agricultural research. In conducting research in Spain, Ashby et al (2000) coined CIAL a Spanish acronym for Comite de Investigation Agricola Local or Local Agriculture Research Committee. CIALs are a form of local agricultural research group belonging to, managed by and providing a service to a rural community. The research team was made up of volunteer farmers, chosen because of their experimentation aptitude and, supported by a facilitator. The CIAL aims to link farmer-researchers with formal research systems, thus increasing local capacity to exert demands on the formal systems and access potentially useful skills, information and research. The CIALs created an opportunity for participants to systematically assess research processes and results and to then translate these reflections into adjustment of the research and management activities. In essence, the CIAL process is one of joint experimentation and learning.

All the 123 farmers who were growing only improved crop varieties (Table 1) stressed the need for them to be part of the planning of the dissemination process. Their reason was that they could offer useful suggestions which would improve the methods of dissemination.

When a Plant Breeder from CSIR was interviewed, he indicated that at the beginning of every year, a planning session is organized for stakeholders (Plant Breeders, Agronomist, Post Harvest Technologist, MOFA and Farmers) in agriculture activities. He said such meetings offer the opportunity for to raise issues concerning the technology, the mode of dissemination and how best the technologies could be adopted. He cited an example that farmers complained of poor husk of obatanpa an improved maize variety which maize breeders addressed by improving the husk cover so that insects cannot easily attack the crop on the field.

Farmers find it extremely difficult to do away with traditional varieties because they maintained that they find them tastier and easier to preserve as compared to the improved varieties. These traits of the traditional varieties have motivated them to continuously cultivate them regardless of the fact that yields were low. The ease of preservation brings to the fore the question of how the dissemination of improved varieties were packaged. The package does not include post- harvest technology to help the farmers to be able to preserve their bumper harvest. In a situation whereby the farmers find it difficult to preserve their produce, it would be a disincentive for them to adopt the improved crop varieties.

Farmers who have adopted wholly or partially improved crop varieties stated that high yield and resistance to drought were the key element that motivated them to adopt the technologies. The farmers contended that in the past poor agronomic practices coupled with use of landraces gave low yields. With the introduction of improved varieties and improved methods of farming yields have improved remarkably.

On what could be done to make adoption of technology easy for the farmers, the farmers mentioned provision of inputs such as fertilizers, chemicals (insecticides and weedicides) as a way of helping farmers to adopt the technologies. There was also the need to create and guaranteed prices to minimize post-harvest losses and ensure guaranteed income for farmers.

In explaining the adoption problem, or lack thereof, farmers stated that the problem does not wholly lie in dysfunctional extension systems or in the poverty of the people in the region. In their view, the lack of market for their excess produce upon adoption of new technologies is the main problem. Hence, many technologies exist but unexploited. Farmers were also unable to adopt them because of resource constraints (World Bank 2003).

Igben (1987) identified non availability of demonstration plots as one of the factors hampering the adoption of farming technologies. Very few farmers advocated more and effective education as the key to improve adoption.

The focus group discussions organized for maize, cassava and oil palm farmers revealed some pertinent issues which need to be addressed. The focus on maize and cassava was that these crops are staple foods which are consumed by people all over the country. Again maize is one of the food security crops under the national buffer stock system which is currently in operation in the northern Ghana.

According to the farmers obatanpa an improved maize variety is good but its storage was a problem. The high weevil infestation makes it difficult to store for a long period. A farmer who has had some knowledge in obatanpa explained that the protein content is high and as such when it is allowed on the field for a long time it attracts the weevil. To solve the problem according to the farmer the crop should be harvested early.

Another issue raised by the farmers was that it cost five hundred Ghana cedis (GH500.00) to cultivate one acre of maize, and ideally adhering to all the agronomical practices, the farmer is expected to get 8 to 9 bags of maize. As a result of insects' infestation and the inability to follow some agronomical practices, one acre maize farm could fetches only 5 bags which when sold at the current market price of the commodity usually make it unprofitable.

The farmers also complained of the cost of seeds of the improved varieties with particular reference to maize. This compels them to select seeds from the previous harvested maize from the field; a situation according to agricultural scientists' is not a good practice. The scientist explained 
further that planting the improved variety near the traditional variety result in contamination of the improved variety. The need for government to subsidize the price of improved variety seeds was stressed by the farmers.

Concerning cassava there is an improved variety known as afisiafi which is good for garri processing aside being equally good for other uses of cassava like fufu preparation. The peel of the variety was a source of worry to the farmers. The peel colour is not the same as the traditional cassava and as such marketing it for other purposes apart from garri processing becomes a problem.

The problem with oil palm according to the farmers is that the seed nuts are expensive making it unaffordable to most of them. The farmers are of the view that some of the improved oil palm varieties were not suitable for the preparation of palm nut soup.

The study revealed that some of the farmers had the perception that growing some of the improved variety was affront to their certain cultural beliefs. One of these cultural beliefs mentioned especially in the Northern Ghana was this festival which had to be celebrated before harvesting of crop (millet) can be done. However in the case where the date of this festival varies, farmers who cultivate early maturing millet stand to lose the crop if it matures before the celebration of the said festival.

Other cultural beliefs were that in certain communities certain crops traits tag the crop a taboo under certain conditions. For example maize cobs with grains of varied colours or twin-bunched plantain are taboos in certain communities.

\section{Recommendation}

The need for government to assists farmers in the acquisition of the planting materials of the improved crop varieties is very crucial to agricultural development of the country. The policy of seed production unit under Ghana Cocoa Board (COCOBOD) to produce improved variety cocoa seeds to sell to farmers at highly subsidized prices is laudable and must be extended to crops in Ghana.

The study also recommends that all stakeholders (Plant Breeders, Agronomists, Post Harvest Technologists, Ministry of Food and Agriculture (MOFA) and Farmers) should be actively involved in the development farming technologies.

\section{References}

[1] Apantaku SO, Olufade O, Adebayo K, Oyekanmi, A. (2008). Analysis of effects of extension teaching methods on farmer's level of cassava and maize production in Ogun State, Nigeria. Ghana Journal of Agriculture Science, 41, Part1.

[2] Ashby JA, Braun AR, Gracia T, Guerrero MP, Hernandez LA, Quiros CA.(2000) committees in Latin America. Cali, Colombia. Centro International de Agricultural Tropical, Working paper No. 5 Washington D.C.
[3] Cohen WM, Levinthal DA. (1990). Absorptive capacity: A new perspective on learning and innovation. Administrative Science Quarterly. 35, 128-152.Inquiry: Rethinking human organizational towards a positive theory of change, StipesPublishing, Chicago

[4] FAO, and World Bank (2000). Agricultural knowledge and information systems for rural development (AKTS/RD): Strategic vision and guiding principles. FAO and World Bank, Rome.

[5] Farinde AJ, Jibowo AA. (1996). Factors associated with effectiveness of extension Teaching methods used in the transfer of agricultural innovation in Lagos State, Nigeria. Paper presented at the $8^{\text {th }}$ Annual Conference of Nigeria Rural Sociological

[6] Association NRSA on Sustainable Rural Development in Nigeria: An Agenda for the Third Republic, March, 1994.

[7] Gabre-Madin EZ, Haggblade S. (2004). Successes in African agriculture: Results of an expert survey. World Development, 32, 745-766.

[8] Heong KL, Escalada MM, Mai V (1994). An analysis of insecticides use in rice: case studies in the Philipines Vietnam International Journal of Pest Management 1994 40(2)173-178.

[9] Igben MS. (1987). Issues and problems in the administration of the Ministry of Agriculture based extension services in Nigeria. Agricultural Administration and Extension, 27, 215-230.

[10] Institute of Statistical Social and Economic Research (2009). A Report on the State of Ghanaian Economy. Accra, ISSER.

[11] Kelsey D, Hearne C. (1995). Co-operative extension work. New York: Comstock Publishing Associates.

[12] Kenyon L, Fowler M. (2000). Factors affecting the uptake and adoption of outputs of crop protection research on yams in Ghana. In S.D. Hainsworth, \& S. J. Eden-Green (Eds.), Sustaining change: proceedings of a workshop on the factors affecting uptake and adoption of outputs of crop protection research in yam. Department for International

[13] Development (DFID) Crop Protection Programme (CPP) research outputs (pp.15-25). Kent, UK.

[14] Norton GA. Mumford JD (1983). Decision making in pest control In: Coaker, T. H.( Ed)Applied Biology Vol 8 Academic Press, New York.

[15] Osabutey PD (2009). Salvaging the agricultural industry through a national fund. The Ghanaian Chronicle.

[16] Rogers EM (1995). Diffusion of innovation, (4 ${ }^{\text {th }}$ ed.). New York: The Free Press.

[17] Röling N, (1995).What to Think of Extension?: A comparison of three models of extension

[18] practice. An Article for Francophone Issue of the AERDD Bulletin. Reading, UK: University of Reading.

[19] Van de Ban AW Hawkin, H. (1988). Agricultural extension. NY: John Wiley and Sons.World Bank. (2000). Attacking Poverty. World Development Report Washington, D. C.: World Bank. 